\title{
Influence of laboratory cultivation on species of Rhodophyta physiological evaluations and antifungal activity against phytopathogens $^{1}$
}

\author{
Influência do cultivo em laboratório em espécies Rhodophyta: avaliações fisiológicas \\ e potencial antifúngico contra fitopatógenos
}

\author{
Levi Pompermayer Machado²*, Silvia Tamie Matsumoto ${ }^{3}$, Geraldo Rogério Faustini Cuzzuol ${ }^{3}$ e Luiz Fernando \\ Ganassali Oliveira $\mathbf{J r}^{4}$
}

\begin{abstract}
The present study examined changes that took place in the physiology of three species of Rhodophyta by analysing the concentration of pigments and non-structural carbohydrates, comparatively evaluating algae collected from nature and after 28 days of laboratory cultivation. Another objective of the study was to determine whether the species retain their antifungal potential after the period of laboratory cultivation, correlating the changes in physiology and those from bioactivity. After carrying out laboratory cultivation, the results indicated a trend, in the three species of macroalgae, towards a reduction in pigment concentrations, mainly in the phycobiliproteins. For the non-structural carbohydrates no response pattern of the macroalgae was observed for the conditions evaluated. Extracts from the macroalgae, Ochtodes secundiramea and Palisada flagellifera, after laboratory cultivation showed a significant increase in antifungal potential which could be positively correlated with the change in concentration and ratios of chlorophyll-a and accessory pigments. Applying techniques of laboratory cultivation to macroalgae was an efficient tool for gaining knowledge of the physiology, and for obtaining biomass and compounds having biotechnological applications, without impacting on natural populations.
\end{abstract}

Key words: Plant physiology. Macroalgae. Nonstructural carbohydrates. Pigments.

RESUMO - O presente estudo verificou as alterações ocorridas na fisiologia de três espécies de Rhodophyta por meio da análise da concentração de pigmentos e de carboidratos não estruturais, avaliando comparativamente algas coletadas da natureza e após 28 dias de cultivo em laboratório. Outro objetivo do estudo foi determinar se as espécies mantêm o potencial antifúngico após o período de cultivo em laboratório, correlacionando as mudanças ocorridas na fisiologia com as de bioatividade. Após a realização de cultivo em laboratório os resultados indicaram a tendência de redução nas concentrações de pigmentos nas três espécies de macroalgas, principalmente para as ficobiliproteínas. Para os carboidratos não estruturais não foi observado padrão de resposta das macroalgas em relação às condições avaliadas. Os extratos das macroalgas Ochtodes secundiramea e Palisada flagellifera, após cultivo em laboratório, apresentaram aumento significativo do potencial antifúngico positivamente correlacionado com a alteração na concentração e nas razões de clorofila $a$ e pigmentos acessórios. A aplicação de técnicas de cultivo em laboratório das macroalgas foi uma ferramenta eficiente para o conhecimento da fisiologia, obtenção de biomassa e de compostos com aplicação biotecnológica, sem impactar populações naturais.

Palavras-chave: Fisiologia vegetal. Macroalgas. Carboidratos não estruturais. Pigmentos.

\footnotetext{
*Autor para correspondência

${ }^{1}$ Recebido para publicação em 17/04/2012; aprovado em 19/09/2013

Parte da Dissertação de Mestrado do primeiro autor apresentada ao programa de Pós-Graduação e Biologia Vegetal - UFES

${ }^{2}$ Instituto de Botânica da Secretaria de Estado do Meio Ambiente, Av. Miguel Estefano, 3687, Água Funda São Paulo-SP Brasil, 04.301-012, levipmachado@yahoo.com.br

${ }^{3}$ Departamento de Ciências Biológicas, Universidade Federal do Espírito Santo, Av. Fernando Ferrari 514, Goiabeiras, Vitoria-ES, Brasil, 29.075-910, siltamie@gmail.com,gcuzzuol@gmail.com

${ }^{4}$ Departamento de Engenharia Agronômica. Universidade Federal de Sergipe, Av. Marechal Rondon, Jardim Roza Elze, São Cristóvão-SE, Brasil, 49.100-000,lfg.ufs@gmail.com
} 


\section{INTRODUCTION}

Since the 1970s seaweeds have gained economic importance due to their potential in the biotechnological application of the polysaccharides: alginates, agarans and carrageenans (BIXLER; PORSE, 2011).

Recent studies with macroalgae have resulted in the discovery of new carbon skeletons in different classes of organic compounds, which show association with uncommon functional groups due to the specificity of the marine environment. These molecules show further potential for their application in the areas of food, agronomy, biofuels, pharmaceuticals and cosmetics (CARDOZO et al., 2007).

In the area of agriculture some species of algae have already been commercialised and used as biostimulants or fertilizers in dried form or as extracts (KHAN et al., 2009). Additionally, the extracts and macroalgae show the potential to act in regulating and eliciting the defense mechanisms of plants against pathogens (PAULERT et al., 2009).

Macroalgae metabolites may have an inhibitory potential against pathogenic microorganisms. Antifungal activity stands out, especially for phytopathogens, due to the rapid formation of resistance by these organisms and the scarcity of products in the market with low toxicity (ARUNKUMAR; SIVAKUMAN; RENGASAMY, 2010).

In Brazil, the papaya is noteworthy, with a production of 1.9 million tonnes on 36.5 hectares, with 30,000 tonnes being exported, having a production value estimated at $\mathrm{R} \$ 1$ billion and making the country the largest producer and exporter in the world (SERRANO; CATTENEO, 2010). Productivity in the papaya is badly affected by the occurrence of anthracnose caused by the fungus Colletotrichum gloeosporioides (Penzig), that affects the fruit during the post-harvest period, causing losses of 30\% (MARTINS; COSTA, 2003).

Several studies have sought to develop alternative techniques for controlling anthracnose through the application of plant extracts (PRAPASSORN et al., 2012) and essential oils (CARNELOSSI et al., 2009), and to evaluate the fungitoxic potential in vitro and in vivo during the post- harvest period (OLIVEIRA et al., 2013).

Recently in Brazil, the application of seaweed extracts as an alternative control in the development of fungi that cause anthracnose has been the subject of several studies that have demonstrated inhibition in the germination of conidia of Colletotrichum sp. when exposed to protein extracts of the macroalgae Hypnea musciformis (MELO et al., 1997). The ethanol extract of 18 species of macroalgae has shown the potential to reduce the severity of anthracnose in the common bean in vivo (ABREU et al., 2008). MACHADO et al. (2011) found that Colletotrichum gloeosporioides in vitro was inhibited when treated with extracts from the species Ochtodes secundiramea and Hypnea musciformis. Recently, Peres et al., (2012) found an inhibitory effect on Colletotrichum lagenarium for terpenes extracted from the macroalga Laurencia dendroidea.

However, the bioprospecting of metabolites derived from marine organisms for research and commercial application has seasonal limitations, which affect both the biomass of the species of interest and its chemical composition, directly affecting the return of the extraction processes. Such limitations can be avoided by cultivating algae on various scales, both in the laboratory and in the field (FRIEDLANDER, 2008).

Cultivation in the laboratory makes it possible to isolate environmental factors, and determine their influence on the metabolism of the algae (BAWEJA et al., 2009) besides enabling production of the relevant metabolites (RORRER; CHENEY, 2004). This technique can be used as a tool in the conservation and improvement of harvested species (YOKOYA; YONESHIGUE-VALENTIN, 2011).

Within this context, the present study compared algae collected in the field and grown in the laboratory, with an aim to determining alterations in the concentrations of pigments and non structural carbohydrates caused by cultivation in the laboratory, and to seeing whether the species maintains its antifungal potential against phytopathogenic fungi after cultivation. Finally, the parameters were correlated so as to investigate the application potential of cultivation in the laboratory in order to obtain the biomass and bioactive extracts of the macroalgae.

\section{MATERIAL AND METHODS}

\section{Organisms evaluated}

The macroalgae Hypnea musciformis (Wulfen) Lamouroux - (Gigartinales), Ochtodes secundiramea (Montagne) Howe - (Gigartinales) and Palisada flagellifera (J. Agardh) Nam - (Ceraminales) have previously been analysed (MACHADO et al., 2011) and were selected for this study due to their potential in inhibiting the development of the agronomically important phytopathogenic fungus, Colletotrichum gloeosporioides (Penzig) Saccardo (Melanconiales), which causes anthracnose in the papaya.

To carry out the experiments, $200 \mathrm{~g}$ fresh weight of macroalgae (equivalent to 20 individuals of each species) were collected from Praia Mole beach in Carapebus, Serra, Espirito Santo $\left(20^{\circ} 14^{\prime} 34^{\prime \prime}\right.$ S, $\left.40^{\circ} 12^{\prime} 54^{\prime \prime} \mathrm{W}\right)$. Harvesting 
took place at $11 \mathrm{am}$, at low tide, and the parameters of both salinity (32 psu), $\mathrm{pH}(8.2)$ and temperature $\left(23.4^{\circ} \mathrm{C}\right)$, were determined in situ using a YSI multiparameter probe.

The removal of visible epiphytic organisms was done in the field, and the algal biomass that was collected was immediately placed into beakers containing sterile seawater, kept in a cooler and taken to the laboratory. Four batches of each species were then removed, each made up of 20 samples from among the individuals collected.

The first two batches, with $10 \mathrm{~g}$ fresh weight of macroalgae, were separated for extraction and analysis of the pigments and non structural carbohydrates respectively. The third batch, of $150 \mathrm{~g}$, was used to obtain the organic extract used for testing bioactivity. Finally the fourth batch, of $30 \mathrm{~g}$, was used in developing the crop in the laboratory. Additionally, dried specimens were produced and deposited in the VIES herbarium, numbered 18,854-18,856.

The fungus Colletotrichum gloeosporioides, which causes anthracnose in the papaya was obtained from a naturallyinfected papaya plantation located in the town of Linhares in Espirito Santo, where it was isolated and forwarded by the Capibaxa Institute for Research, Technical Assistance and Rural Extension [Instituto Capixaba de Pesquisa, Assistência Técnica e Extensão Rural] (INCAPER), cultured on a PDA (Potato, Dextrose and Agar) medium.

\section{Cultivation of macroalgae in the laboratory}

In the laboratory, algae from batch 4 (30g fresh weight) were cleaned with paper and tweezers under a stereomicroscope and treated chemically in order to obtain unialgal cultures. First, the macroalgae were treated with a solution of sodium hypochlorite in sterile sea water at a concentration of 1:1000 (v:v) for one minute. The stalks were then treated for one day with germanium dioxide $\left(\mathrm{GeO}_{2}\right)$, at a concentration of $2 \mathrm{~mL} \mathrm{~L}^{-1}$, and the antibiotic ciprofloxacin (CIPRO ${ }^{\circledR}$ ), at $10 \mathrm{mg} \mathrm{L}^{-1}$, both diluted in sterile sea water (BAWEJA et al., 2009; FERNANDES; YOKOYA; YONESHIGUE-VALENTIN, 2011). After these treatments, the experimental period of laboratory cultivation began.

The culture medium consisted of seawater taken from the same place the macroalgae were collected (32 ups salinity and a $\mathrm{pH}$ of 8.2 ), sterilised by filtration through a 0.45 membrane (Millipore HA) and placed twice in a hot-water bath for 60 minutes. A von Stosch nutrient solution at $4 \mathrm{~mL} \mathrm{~L}^{-1}$ was added (Edwards, 1970) with a $50 \%$ reduction in the vitamin concentrations (Table 1). Maintenance of the culture was effected with a weekly change of the medium (YOKOYA et al., 2007).

Additionally the percentage increase in biomass was determined by weekly measurements of the fresh weight of the algae whilst the medium was being changed during
Table 1 - Chemical composition of the von Stosch solution prepared according Edwards (1970)

\begin{tabular}{lc}
\hline \multicolumn{1}{c}{ Substance } & Final concentration \\
\hline $\mathrm{NaNO}_{3}$ & $0,50 \mathrm{mM}$ \\
$\mathrm{Na}_{2} \mathrm{HPO}_{4} \cdot 12 \mathrm{H}_{2} \mathrm{O}$ & $30 \mu \mathrm{M}$ \\
$\mathrm{FeSO}_{4} \cdot 7 \mathrm{H}_{2} \mathrm{O}$ & $1 \mu \mathrm{M}$ \\
$\mathrm{MnCl}_{2} \cdot 4 \mathrm{H}_{2} \mathrm{O}$ & $0,1 \mu \mathrm{M}$ \\
$\mathrm{Na}_{2} \mathrm{EDTA} \cdot 2 \mathrm{H}_{2} \mathrm{O}$ & $10 \mu \mathrm{M}$ \\
$\mathrm{Thiamine}_{\mathrm{HCl}}$ & $0,59 \mu \mathrm{M} *$ \\
Biotin & $4,10 \mathrm{nM} *$ \\
Cyanocobalamin & $1,0 \mathrm{nM} *$ \\
\hline
\end{tabular}

*50\% reduction in vitamin concentrations

maintenance, and the relative growth rate (RGR) for each species calculated as described by Reis et al. (2003).

The system of cultivation was of five simultaneous replications $(n=5)$ in Erlenmeyer flasks containing $800 \mathrm{ml}$ of the culture medium with $6 \mathrm{~g}$ initial fresh weight of macroalgae per flask. Cultivation was carried out under the following conditions: temperature of $24^{\circ} \mathrm{C} \pm 2{ }^{\circ} \mathrm{C}$, irradiance of $40 \pm 5 \mu \mathrm{mol} \mathrm{m} \mathrm{s}^{-1}$ (400-700 nm) from fluorescent lamps (20W, daylight) arranged over the bottles, with a photoperiod of 14:10 (light: dark). In addition, aeration was carried out intermittently with moist air.

\section{Analysis of pigments and carbohydrates}

The pigment content was determined both for the macroalgae collected directly in the field and after 28 days of cultivation in the laboratory. In order to extract the pigments, $100 \mathrm{mg}$ fresh weight of each species of macroalgae, with 5 replications $(n=5)$, were macerated in liquid nitrogen, suspended in $1 \mathrm{~mL}$ of a $50 \mathrm{mM}$

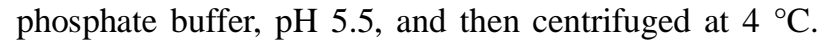
The supernatant was collected and used in determining the total phycobiliproteins; this being the sum of the allophycocyanin, phycocyanin and phycoerythrin.

The residue was again suspended in $\operatorname{DMF}(\mathrm{N}, \mathrm{N}-$ dimethylformamide) and kept for 24 hours in the dark at $5{ }^{\circ} \mathrm{C}$ to extract the chlorophyll- $a$ and total carotenoids. Quantification of the pigments was carried out using a visible-UV spectrophotometer employing the wavelengths and formulas for chlorophyll- $a$. Total carotenoids and each of the phycobiliproteins (YOKOYA et al., 2007) were calculated as the ratios of the chlorophyll- $a$ to total phycobiliproteins, and the chlorophyll- $a$ to total carotenoids.

The extraction of non-structural carbohydrates was performed using $1 \mathrm{~g}$ fresh weight of macroalgae both 
from the field and grown in the laboratory $(n=5)$. The samples were macerated in $80 \%$ ethanol at $80{ }^{\circ} \mathrm{C}$ for 15 minutes. Centrifugation at 3,000 g for 15 minutes was then carried out, with the hydroalcoholic supernatant being collected and concentrated in a rotary evaporator at $60{ }^{\circ} \mathrm{C}$ ) and used to quantify the glucose, fructose and sucrose content. The residue from the centrifugation was suspended in distilled water and $52 \%$ perchloric acid for 15 minutes at $5{ }^{\circ} \mathrm{C}$ and then centrifuged at $3,000 \mathrm{~g}$ for 15 minutes, the supernatant being collected for the analysis of starch (CLIPPEL; CUZZUOL, 2009).

Non-structural carbohydrate analysis was performed colorimetrically employing acid hydrolysis with Anthrone, in a visible-UV spectrophotometer, at a wavelength of $620 \mathrm{~nm}$ with the measurement being determined by comparison with a standard absorbance curve for the specific concentration of each carbohydrate. The free glucose content in the extracts was determined by the enzymatic method (BioSystem kit), incubating at $25^{\circ} \mathrm{C}$ for 5 minutes, with readings taken at $500 \mathrm{~nm}$.

\section{Test for antifungal activity}

The fungal matrices for $C$. gloeosporioides (anthracnose in the papaya) were conserved on a PDA medium and maintained at $28{ }^{\circ} \mathrm{C}$. Mycelia were removed from these fungi to prepare a suspension of conidia in sterile water at a concentration of $10^{5}$ conidia $\mathrm{mL}^{-1}$, as counted with a Neubauer chamber.

The organic extract for performing the tests was obtained using fresh macroalgae treated with a dichloromethane/methanol solvent mixture $(2: 1)$ at a ratio of $1 \mathrm{~g}$ of macroalgae per $10 \mathrm{ml}$ of solvent mixture. After seven days the extract was concentrated in a rotary evaporator at $50{ }^{\circ} \mathrm{C}$.

The extract from each of the macroalgae was diluted directly in a PDA medium at a final concentration of $5 \mu \mathrm{g} \mathrm{m} \mathrm{L}^{-1}$ (MACHADO et al., 2011) in order to evaluate the antifungal potential by measuring the diameter of the growth halo, with the percentage of inhibition being calculated by comparing the treatments of algal extracts $(n=5)$ to the negative control, which contained only PDA and the fungus.

The mycelial growth index (MGI) was determined by measuring the diameter of the colonies and applying the formula described by Dias et al. (2005); the percentage of inhibition was determined by comparing the samples treated with the extracts from algae collected in the field to those cultivated with the negative control, which contained only culture medium and fungus, and the positive control containing the commercial antifungal agent $\AA$ Prochloraz.

\section{Analysis of the results}

All the analyses in this study were carried out on algae collected directly from the field, or after a period of cultivation in the laboratory. The experiments were conducted using a completely randomised design with five independent samples $(n=5)$ and three simultaneous replications for each analysis. The results (the difference between the values obtained with algae from the field and with algae after a period of laboratory cultivation) were subjected to variance analysis (ANOVA) by the Tukey test, in the case of Ho rejection ( $p<0.01)$, determination of significant changes in the values of the non-structural carbohydrates, pigments and bioactivity was evaluated by the Tukey test (ASSISTAT 7.5 beta).

The results of bioactivity in the organic extract from the algae under both field and laboratory conditions were correlated with the carbohydrate and pigment concentrations using the Spearman correlation index ( $p<0.01$ ), seeking to identify possible relationships between the ecophysiology and the bioactivity in the algae under field and laboratory conditions.

\section{RESULTS AND DISCUSSION}

Under laboratory cultivation, H. musciformis presented a daily relative growth rate of $0.036 \pm$ $0.009 \mathrm{~g} \mathrm{day}^{-1}$, P. flagellifera presented a rate of 0.016 $\pm 0.006 \mathrm{~g} \mathrm{day}^{-1}$ and $O$. secundiramea a rate of $0.008 \mathrm{~g}$ $\pm 0.002 \mathrm{day}^{-1}$. The percentage increase in the biomass of the macroalgae during the 28 days of cultivation is shown in Figure 1.

Figure 1 - Percentage increase in the fresh biomass of the macroalgae (6 $\mathrm{g}$ initial fresh weight per beaker) throughout the 28 days of laboratory cultivation. Bars indicate standard deviations $(\mathrm{n}=5)$

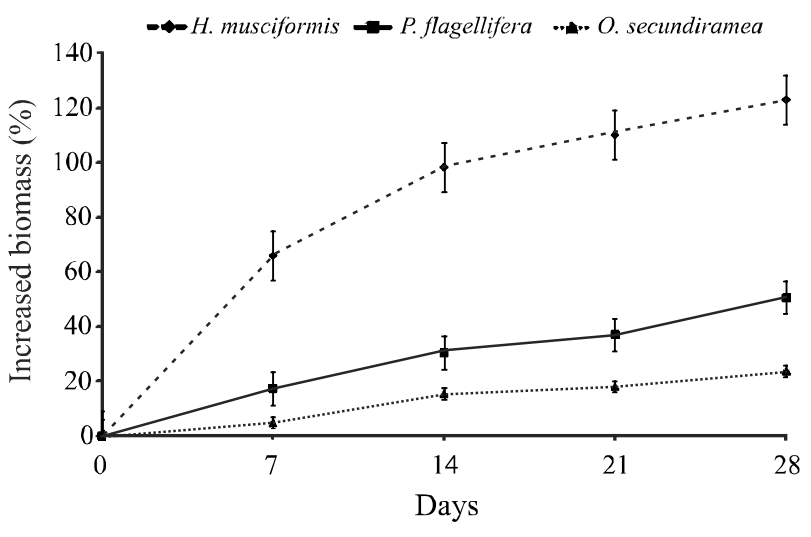


The species $H$. musciformis presented the greatest RGR for the cultivation period of $3.6 \%$ per day, equivalent to results observed by Reis et al. (2003), for algae collected in the field and then cultured in the laboratory, being however $50 \%$ less than that obtained by Yokoya et $a l$. (2007) for unialgal cultures set up in the laboratory.

The values obtained for $O$. secundiramea were lower than the results of Polzin and Rorrer (2003) for the cultivation of regenerated plants of this species carried out in bioreactors. This study is the first report of the laboratory cultivation of the species $P$. flagellifera.

After laboratory cultivation, significant changes were detected in relation to the field samples in the species $O$. secundiramea and $P$. flagellifera. For $O$. Secundiramea, there was a reduction in the concentrations of chlorophyll- $a(\mathrm{~F}=26.3377, \mathrm{p}<0.001)$ and phycoerythrin $(\mathrm{F}=14.8426, \mathrm{p}=0.0032)$ and in the ratio of chlorophyll- $a$ to carotenoid $(\mathrm{F}=107.9268, \mathrm{p}<0.001)$.

The species $P$. flagellifera showed significant decreases in the ratios of chlorophyll to carotenoids $(\mathrm{F}=43.6402, \mathrm{p}<0.001)$ and to phycobiliproteins $(\mathrm{F}=$ $174.5873, \mathrm{p}<0.001)$, as well as to total phycobiliprotein $(\mathrm{F}=50.3669, \mathrm{p}<0.001)$ and to allophycocyanin $(\mathrm{F}=$ $50.0734, \mathrm{p}<0.001)$, FC $(=27.0727, \mathrm{p}<0.001)$ and phycoerythrin $(\mathrm{F}=58.782, \mathrm{p}<0.001)$. The species
H. musciformis showed no significant changes in concentrations of the evaluated pigments under natural or cultivated conditions (Table 2).

The macroalgae evaluated showed different response patterns when transferred from field to laboratory conditions. Significant reductions in the concentrations of the total phycobiliproteins (allophycocyanin, phycocyanin and phycoerythrin) seen in P. Flagallifera, and of phycoerythrin and chlorophyll$a$ in $O$. Secundiramea, are associated with changes in the quality and quantity of light between field and laboratory conditions, characterised as short-term acclimatisation (TALARICO; MARAZANA, 2000).

The significant reduction in the ratio of chlorophyll- $a$ to carotenoids seen in $O$. secundiramea and $P$. flagellifera under laboratory conditions, is an indication of the activation of photoprotection mechanisms and oxidative stress associated with the change in photosynthetically active radiation (BAUTISTA; NECCHI JÚNIOR, 2007).

Barufi et al. (2011) found that the low availability of nitrogen promotes a reduction in the concentration of carotenoids in Rhodophyta. The absence of any significant change in the concentration of total

Table 2 - Pigment concentrations, expressed in $\mu \mathrm{g} \mathrm{g}^{-1}$ macroalgae fresh weight, and ratios chlorophyll-a/total carotenoids, chlorophyll-a/total phycobiliproteins and standard deviations $(\mathrm{n}=5)$

\begin{tabular}{lcccc}
\hline \multirow{2}{*}{ Pigments } & Condition & \multicolumn{3}{c}{ Algae } \\
\cline { 3 - 5 } & & Hypnea musciformis & Palisada flagellifera & Ochtodes secundiramea \\
\hline \multirow{2}{*}{ Chlorophyll-a } & Field & $246.68 \pm 20.78$ & $148.67 \pm 33.61$ & $299.92 \pm 43.31 \mathrm{a}$ \\
& Culture & $187.72 \pm 67.68$ & $134.93 \pm 27.87$ & $218.59 \pm 23.78 \mathrm{~b}$ \\
Total carotenoids & Field & $79.30 \pm 6.51$ & $37.02 \pm 4.19$ & $58.17 \pm 10.85$ \\
& Culture & $61.49 \pm 22.23$ & $46.28 \pm 9.92$ & $56.70 \pm 7.72$ \\
Chlorophyll-a / Carotenoids & Field & $3.11 \pm 0.04$ & $4.00 \pm 0.43 \mathrm{a}$ & $5.18 \pm 0.55 \mathrm{a}$ \\
& Culture & $3.05 \pm 0.08$ & $2.92 \pm 0.12 \mathrm{~b}$ & $3.85 \pm 0.18 \mathrm{~b}$ \\
Allophycocyanin & Field & $0.97 \pm 0.59$ & $1.63 \pm 0.26 \mathrm{a}$ & $0.56 \pm 0.25$ \\
Phycocyanin & Culture & $0.30 \pm 0.1$ & $0.61 \pm 0.1 \mathrm{~b}$ & $0.46 \pm 0.2$ \\
Phycoerythrin & Field & $0.36 \pm 0.28$ & $0.72 \pm 0.24 \mathrm{a}$ & $0.16 \pm 0.09$ \\
& Culture & $0.08 \pm 0.02$ & $0.09 \pm 0.02 \mathrm{~b}$ & $0.07 \pm 0.01$ \\
Total phycobiliprotein & Field & $0.83 \pm 0.67$ & $1.30 \pm 0.23 \mathrm{a}$ & $0.50 \mathrm{a} \pm 0.12$ \\
Chlorophyll-a & Culture & $0.15 \pm 0.05$ & $0.39 \pm 0.04 \mathrm{~b}$ & $0.26 \mathrm{~b} \pm 0.03$ \\
Phycobiliproteins & Field & $2.15 \pm 1.73$ & $3.65 \pm 1.09 \mathrm{a}$ & $1.23 \pm 0.78$ \\
\hline & Culture & $0.53 \pm 0.17$ & $0.93 \pm 0.22 \mathrm{~b}$ & $0.79 \pm 0.05$
\end{tabular}

Mean values followed by different letters differ between themselves by the Tukey test, for field or laboratory conditions, at $1 \%$ significance 
carotenoids in the evaluated macroalgae indicates that the conditions which developed under laboratory cultivation did not expose the algae to any deficit of this nutrient in relation to conditions in the field.

H. musciformis is widely distributed along the Brazilian coast due to high physiological plasticity (REIS et al., 2003). In the present study, no significant changes were observed in the concentrations of pigments between field and laboratory conditions. Potential for the development of crop platforms for exploration of the species should be noted, due to its capacity to produce carrageenans and sulfated polysaccharides with a high aggregate value (BIXLER; PORSE, 2011).

H. musciformis showed a significant increase in sucrose concentration $(\mathrm{F}=11.4103, \mathrm{p}=0.007)$. For the monosaccharides there was a significant reduction in fructose for $P$. flagellifera $(\mathrm{F}=24.2252, \mathrm{p}<0.001)$ and an increase in glucose for $O$. secundiramea $(\mathrm{F}=933.8193$, $\mathrm{p}<0.001)$. The reserve product, floridian starch, showed a decrease for $P$. flagellifera (F 21.4455, $\mathrm{p}<0.001)$ and increase for $O$ secundiramea $(\mathrm{F}=12.9008, \mathrm{p}=0.0049)$, the same being observed for the starch to sucrose ratio in both species $(\mathrm{F}=18.4157, \mathrm{p}=0.0016)$ and $(\mathrm{F}=16.9624$, $\mathrm{p}=0.0021$ ) respectively (Table 3 ).

An increase in the sucrose concentration was verified for $H$. musciformis under laboratory conditions in relation to material from the field. This increase was accompanied by a high rate of growth in the laboratory culture (Figure 1), a fact that can be explained by this carbohydrate being indicative of metabolism and associated with growth and development in plants (LAMBERS; CHAPIN; PONS, 2008).

The significant increase in the concentrations of glucose and starch for $O$. secundiramea and of sucrose in $H$. musciformis under laboratory conditions, demonstrates the potential for application of these techniques in the exploitation of bioethanol (GOH; LEE, 2010).

The high concentrations of fructose and starch seen for P. flagllifera under field and laboratory conditions, indicate the potential for application of this species in the food industry (VORAGEN, 1998).

The present study found no significant differences between field and laboratory conditions for the concentration of total sugars using the method used by Marinho-Soriano (2006), Gordillo, Aquilera and Jimenez (2006) Luong-Van and Renaud (2006) and Perfeto, Schwarbold and Dillerburg (2005). However, evaluation of the concentrations of non structural carbohydrates (glucose, fructose, sucrose and starch) showed a greater sensitivity in response to different conditions in ecophysiological investigations of the macroalgae.

Cultivation in the laboratory caused a significant increase in the antifungal potential of the macroalgae extracts for $O$. secundiramea $(\mathrm{F}=20.993, \mathrm{p}=0.009)$ and $P$. flagellifera $(\mathrm{F}=108.255, \mathrm{p}<0.001)$ in controlling the phytopathogen, C. gloeosporioides (Table 4).

Table 3 - Concentration of non structural carbohydrates expressed in $\mu \mathrm{g} \mathrm{g} \mathrm{g}^{-1}$ macroalgae fresh weight with the sucrose to starch ratio and standard deviations $(\mathrm{n}=5)$.

\begin{tabular}{lcccc}
\hline \multirow{2}{*}{ Carbohydrates } & Condition & \multicolumn{3}{c}{ Algae } \\
\cline { 3 - 5 } & & Hypnea musciformis & Palisada flagellifera & Ochtodes secundiramea \\
\hline \multirow{2}{*}{ Sucrose } & Field & $133,80 \pm 40,52 \mathrm{~b}$ & $308,84 \pm 47.48$ & $198.77 \pm 33.55$ \\
& Culture & $199.87 \pm 12.17 \mathrm{a}$ & $367.96 \pm 16.36$ & $169.13 \pm 11.15$ \\
Glucose & Field & $0.49 \pm 0.18$ & $0.45 \pm 0.08$ & $0.15 \pm 0.03 \mathrm{~b}$ \\
& Culture & $0.35 \pm 0.01$ & $0.34 \pm 0.04$ & $0.74 \pm 0.01 \mathrm{a}$ \\
Starch & Field & $647.19 \pm 262.67$ & $2407.97 \pm 229.67 \mathrm{a}$ & $508.80 \pm 114.83 \mathrm{~b}$ \\
& Culture & $564.74 \pm 58.89$ & $1808.77 \pm 16.19 \mathrm{~b}$ & $784.11 \pm 80.97 \mathrm{a}$ \\
Fructose & Field & $5.02 \pm 0.58$ & $59.25 \pm 9.14 \mathrm{a}$ & $2.24 \pm 1.64$ \\
& Culture & $5.99 \pm 0.1$ & $32.26 \pm 0.91 \mathrm{~b}$ & $4.68 \pm 0.88$ \\
Total sugars & Field & $180.33 \pm 66.39$ & $927.33 \pm 162.78$ & $538.17 \pm 265.56$ \\
& Culture & $293.39 \pm 53.48$ & $1,018.03 \pm 89.03$ & $365.94 \pm 36.11$ \\
Sucrose/starch & Field & $0.24 \pm 0.09$ & $0.13 \pm 0.03 \mathrm{~b}$ & $0.41 \pm 0.09 \mathrm{a}$ \\
& Culture & $0.36 \pm 0.04$ & $0.20 \pm 0.01 \mathrm{a}$ & $0.22 \pm 0.01 \mathrm{~b}$ \\
\hline
\end{tabular}

Mean values followed by different letters differ between themselves by the Tukey test, for field or laboratory conditions, at $1 \%$ significance 
Table 4 - Mycelial growth index (MGI) and percentage inhibition of Colletotrichum gloeosporioides when exposed to organic extracts of macroalgae at a concentration of $5 \mu \mathrm{g} \mathrm{mL} \mathrm{L}^{-1}$, under field and laboratory conditions

\begin{tabular}{clccccc}
\hline \multirow{2}{*}{ Condition } & \multicolumn{5}{c}{ Treatments } \\
\cline { 2 - 6 } & $\begin{array}{c}\text { Hypnea } \\
\text { musciformis }\end{array}$ & $\begin{array}{c}\text { Palisada } \\
\text { flagellifera }\end{array}$ & $\begin{array}{c}\text { Ochtodes } \\
\text { secundiramea }\end{array}$ & $\begin{array}{c}\text { Negative } \\
\text { control }\end{array}$ & $\begin{array}{c}\text { Positive } \\
\text { control }\end{array}$ \\
\hline \multirow{2}{*}{ MGI (cm.day ${ }^{-1}$ ) } & Field & $4.70 \pm 0.08 \mathrm{Ca}$ & $6.31 \pm 0.05 \mathrm{Ba}$ & $1.31 \pm 0.08 \mathrm{Da}$ & $8.47 \pm 0.14 \mathrm{~A}$ & $0.00 \mathrm{~F}$ \\
& Culture & $4.62 \pm 0.09 \mathrm{Ca}$ & $4.96 \pm 0.13 \mathrm{Cb}$ & $0.92 \pm 0.14 \mathrm{Ea}$ & $8.47 \pm 0.14 \mathrm{~A}$ & $0.00 \mathrm{~F}$ \\
& Field & $44.48 \pm 0.09 \mathrm{Ca}$ & $25.58 \pm 0.66 \mathrm{Ba}$ & $84.52 \pm 0.16 \mathrm{Da}$ & $0.00 \mathrm{~A}$ & $100 \mathrm{~F}$ \\
& Culture & $45.48 \pm 1.07 \mathrm{Ca}$ & $41.47 \pm 1.56 \mathrm{Cb}$ & $89.19 \pm 1.64 \mathrm{Ea}$ & $0.00 \mathrm{~A}$ & $100 \mathrm{~F}$ \\
\hline
\end{tabular}

Mean values followed by the same lower-case letter in a column (comparison between field and laboratory conditions) and the same upper-case letter on a line (comparison between different species of macroalgae and the controls) don't differ among themselves by the Tukey test at $1 \%$ significance

The results for antifungal activity corroborate those of Machado et al., (2011) who found inhibition of mycelial growth in C. gloeosporioides of approximately $90 \%$ for $O$. secundiramea and around $50 \%$ for $H$. musciformis.

The species $P$. flagellifera, a member of the Laurencia complex, did not show the high antifungal activity similar to other species of the same group evaluated by Machado et al., (2011) and Peres et al. (2012).

Garcia et al. (2008) found that plant essential oils rich in terpenes exhibit fungitoxic activity against phytopathogens. The inhibitory activity against $C$. gloeosporioides may be explained by the existence of isolated sesquiterpenes in algae of the Laurencia complex, which includes the genera Chondrophycus, Laurencia, Palisada, Osmundea and Yuzurua (FUJII et al., 2011) and the genus Hypnea (AFAQ-HUSAIN et al., 1991), and of monoterpenes, identified for the genus Ochtodes (POLZIN; RORRER, 2003).

Application of the Spearman correlation index (Table 5) indicated that for the species P. Flagellifera, changes in the ratios of chlorophyll- $a$ to carotenoids and chlorophyll- $a$ to phycobiliproteins show significant positive correlation to the increased bioactivity seen under laboratory conditions. For $O$. secundiramea this correlated positively with a significant decrease in the chlorophyll- $a$ concentrations observed in the laboratory.

The changes in the concentration of chlorophyll$a$, and in the values of chlorophyll- $a$ to carotenoids and chlorophyll- $a$ to phycobiliproteins, is a response to the possible oxidative stress suffered by the algae under laboratory conditions (BAUTISTA; NECCHI JÚNIOR.2007).

Table 5 - Spearman correlation indices for antifungal activity of organic extracts and the ecophysiological parameters evaluated for macroalgae under field and laboratory conditions

\begin{tabular}{|c|c|c|c|c|}
\hline \multirow{2}{*}{ Parameters } & \multirow{2}{*}{ Condition } & \multicolumn{3}{|c|}{ 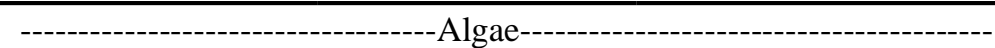 } \\
\hline & & Hypnea musciformis & Palisada flagellifera & Ochtodes secundiramea \\
\hline \multirow{2}{*}{ Sucrose/Starch } & Field & -0.402 & -0.422 & 0.246 \\
\hline & Culture & 0.629 & -0.572 & 0.503 \\
\hline \multirow{2}{*}{ Glucose } & Field & -0.519 & -0.082 & 0.563 \\
\hline & Culture & -0.769 & 0.462 & 0.776 \\
\hline \multirow{2}{*}{ Sucrose } & Field & 0.559 & -0.201 & -0.524 \\
\hline & Culture & -0.350 & -0.632 & -0.780 \\
\hline \multirow{2}{*}{ Fructose } & Field & 0.272 & -0.167 & -0.490 \\
\hline & Culture & 0.446 & -0.440 & -0.599 \\
\hline \multirow{2}{*}{ Starch } & Field & 0.794 & 0.782 & -0.891 \\
\hline & Culture & -0.779 & 0.179 & -0.709 \\
\hline
\end{tabular}


Continuation of Table 5

\begin{tabular}{lcccc}
\hline \multirow{2}{*}{ Total sugars } & Field & -0.068 & -0.315 & -0.427 \\
& Culture & -0.641 & -0.457 & 0.779 \\
Chlorophyll-a/ Carotenoides & Field & -0.833 & 0.262 & 0.330 \\
& Culture & 0.423 & $0.977^{*}$ & 0.882 \\
Chlorophyll-a/ & Field & 0.478 & -0.885 & $-0.934^{*}$ \\
Phycobiliproteins & Culture & 0.811 & $0.989^{*}$ & $0.955^{*}$ \\
Chlorophyll-a & Field & -0.770 & 0.641 & 0.722 \\
& Culture & 0.916 & -0.186 & $0.922^{*}$ \\
Carotenoids & Field & -0.675 & 0.917 & 0.413 \\
& Culture & 0.892 & -0.420 & 0.847 \\
Phycoerythrin & Field & -0.215 & 0.469 & 0.919 \\
& Culture & 0.661 & -0.653 & 0.669 \\
Phycocyanin & Field & -0.097 & $0.967 *$ & 0.854 \\
& Culture & -0.580 & -0.761 & -0.817 \\
Allophycocyanin & Field & -0.125 & 0.665 & 0.902 \\
& Culture & 0.609 & -0.723 & 0.002 \\
Phycobiliproteins & Field & -0.157 & 0.745 & 0.898 \\
& Culture & 0.914 & -0.713 & 0.300 \\
\hline
\end{tabular}

Values followed by $(*)$ are significant between conditions $(\mathrm{p}<0.01)$

According to Dring (2006), under these conditions the macroalgae start to synthesize sequestering compounds of oxygen-reactive species. In macroalgae, the production of halogenated terpenes stands out among these metabolites as a class of compound having extensive bioactive potential (KORNPROBST; AL-EASA, 2003).

\section{CONCLUSIONS}

1. The results highlight the potential of macroalgal substances, especially from Ochtodes secundiramea, in inhibiting the development of phytopathogenic fungi of agronomic importance;

2. Under laboratory conditions, the species $O$. secundiramea and P. flagellifera showed changes which may be associated with oxidative stress, and which were positively correlated to increased antifungal activity, indicating the possibility of applying this technique to induce the synthesis of bioactive compounds in macroalgae;

3. Growth values, and the absence of significant changes for the species $H$. musciformis under laboratory conditions, underline the possibility of applying these techniques to obtain biomass and carrageenan;

4. Evaluation of the free monosaccharides in stalks of the algae, was more sensitive to changes in environmental conditions than the conventionally used parameter of total sugars. The fructose values obtained for P. flagellifera are unprecedented, demonstrating the possible application of this macroalga as a functional food.

\section{ACKNOWLEDGEMENTS}

To Conselho Nacional de Desenvolvimento Científico e Tecnológico (CAPES) for the scholarship granted to the first author.

\section{REFERENCES}

ABREU, G. F. et al. Bioprospecção de macroalgas marinhas e plantas aquáticas para o controle da antracnose do feijoeiro. Summa Phytopathologica v. 34, n. 1, p. 78-82, 2008.

AFAQ-HUSAIN, S. et al. Brominated sesquiterpene metabolites of Hypnea pannosa (Gigartinales, Rhodophyta). Journal of Applied Phycology, v. 3, n. 2, p. 111-113, 1991. 
ARUNKUMAR, K.; SIVAKUMAR, S. R.; RENGASAMY, R. A reviw on bioative potential in seaweeds (marine macroalgae): a special emphasis on bioative of seaweeds against plant pathogens. Asian Journal of Plant Sciences, v. 9 , n. 5, p. 227-240, 2010 .

BARUFI, J. B. et al. Effects of N supply on the accumulation of photosynthetic pigments and photoprotectors in Gracilaria tenuistipitata (Rhodophyta) cultured under UV radiation. Journal of Applied Phycology, v. 23, n. 3, p. 457-466, 2011.

BAUTISTA, A. I. N.; NECCHI JÚNIOR, O. Photoacclimation in three species of freshwater red algae. Brazilian. Journal Plant Physiology, v. 19, n. 1, p. 23-24, 2007.

BAWEJA, P. et al. Seaweed tissue culture as applied to biotechnology: Problems, achievements and prospects. Phycological Research, v. 57, n. 1, p. 45-58, 2009.

BIXLER, H. J.; PORSE H. A decade of change in the seaweed hydrocolloids industry. Journal of Applied Phycology, v. 23, n. 3, p. 321-335, 2011.

CARDOZO, K. H. M. et al. Metabolites from algae with economical impact. Comparative Biochemistry and Physiology. C, Toxicology \& Pharmacology, v. 146, n. 1/2, p. $60-78,2007$

CARNELOSSI, P. R. et al. Óleos essenciais no controle pós-colheita de Colletotrichum gloeosporioides em mamão. Revista Brasileira de Plantas Medicinais, v. 11, n. 4, p. 399406, 2009.

CLIPPEL, J. K.; CUZZUOL, G. R. F. Aspectos ecofisiológicos de Sinningia aghensis Chautems em condições de campo. Hoehnea, v. 36, n. 1, p. 73-81, 2009.

DIAS, M. D. et al. Efeito da temperatura no crescimento micelial, produção e germinação de conídios de Colletotrichum spp. Isolados de Coffea arabica 1 . Ciência e Agrotécnologia, v. 29, n. 3, p. 545-552, 2005.

DRING, M. J. Stress resistance and disease resistance in seaweeds: the role of reactive oxygen metabolism, Advances in Botanical Research, v. 43, p. 175-207, 2006.

EDWARDS P. Illustrated guide to the seaweeds and seagrasses in the vicinity of Porto Aransas, Texas. Contribuition Marine Science, v. 15 p. 1-228, 1970.

FERNANDES, D. R. P.; YOKOYA, N. S.; YONESHIGUEVALENTIN, Y. Protocol for seaweed decontamination to isolate unialgal cultures. Revista Brasileira de Farmacognosia, v. 21, n. 2, p. 313-316, 2011.

FRIEDLANDER, M. Israeli $\mathrm{R} \& \mathrm{D}$ activities in seaweed cultivation. Israel Journal of Plant Sciences, v. 56, n. 1/2, p. 15-28, 2008.

FUJII, M. T. et al. Overview of the taxonomy and of the major secondary metabolites and their biological activities related to human health of the Laurencia complex (Ceramiales, Rhodophyta) from Brazil. Revista Brasileira de Farmacognosia, v. 21, n. 2, p. 268-282, 2011.
GARCIA, R. et al. Antimicrobial activity and potential use of monoterpenes as tropical fruits preservatives. Brazilian Journal of Microbiology, v. 39, n. 1, p. 163-168, 2008.

GOH, C. S.; LEE, K. T. A visionary and conceptual macroalgae-based third-generation bioethanol (TGB) biorefinery in Sabah, Malaysia as an underlay for renewable and sustainable development. Renewable and Sustainable Energy Reviews, v. 14, n. 2, p. 842-848, 2010.

GORDILlo, F. J. L.; AGUILERA, J.; JIMÉNEZ, C. The response of nutrient assimilation and biochemical composition of Arctic seaweeds to a nutrient input in summer. Journal of Experimental Botany, v. 57, n. 11, p. 2661-2671, 2006.

KHAN, W. et al. Seaweed Extracts as Biostimulants of Plant Growth and Development. Journal of Plant Growth Regulation, v. 28 n. 4, p. 386-399, 2009.

KORNPROBST, J. M.; AL-EASA, H. S. Brominated Diterpenes of Marine Origin, Current Organic Chemistry, v. 7, n. 1, p. 1181-1229, 2003.

LAMBERS, H.; CHAPIN III, F. S.; PONS, T. L. Plant Physiological Ecology. 2nd ed. Springer Verlag: New York, 2008. 610 p.

LUONG-VAN, J. T.; RENAUD, S. M. Seasonal variation in the chemical composition of tropical Australian marine macroalgae. Journal of Applied Phycology, v. 18, p. 381387, 2006.

MACHADO, L. P. et al. Triagem de macroalgas com potencial antifúngico no controle in vitro da antracnose do mamoeiro (Carica papaya L.). Revista Brasileira de Agrociência, v. 17, n. 4, p. 463-467, 2011.

MARINHO-SORIANO E. et al. Seasonal variation in the chemical composition of two tropical seaweeds. Bioresource Technology, v. 97, n. 18, p. 2402-2406, 2006.

MARTINS, D. dos S.; COSTA, A. de F.S. da. A Cultura do Mamoeiro: Tecnologias de Produção. Vitória ES: Incaper, 2003. 497 p.

MELO, V. M. M. et al. Antifungal properties of proteins (agglutinins) from the red alga Hypnea musciformis (wulfen) lamouroux. Botanica Marina, v. 40, n. 1/6, p. 281-284, 1997.

OLIVEIRA, L. F. G. et al. Efeito fungitóxico do óleo essencial de aroeira da praia (Schinus terebinthifolius RADDI) sobre Colletotrichum gloeosporioides. Revista Brasileira de Plantas Medicinais, v. 15, n. 1, p. 150-157, 2013.

PAULERT R. et al. Effects of sulfated polysaccharide and alcoholic extracts from Green seaweed Ulva fasciata on anthracnose severity and growth of common bean (Phaseolus vulgaris L.). Journal of Plant Diseases and Protection, v. 116, n. 6, p. 263-270, 2009.

PRAPASSORN B. et al. Effect of Crude Leaf Extracts on Colletotrichum gloeosporioides (Penz.) Sacc. Psyche, 2012. Disponível em: <http://www.hindawi.com/journals/ psyche/2012/309046/>. Acesso em: 10 ago. 2013.

PERES, J. C. F. et al. Evaluation of antifungal activity of seaweed extracts. Ciência e Agrotecnologia, v. 36, n. 3, p. 294-299, 2012. 
PERFETO, P. N. M.; SCHWARZBOLD, A.; DILLENBURG, L. R. Efeitos da salinidade, temperatura e concentração de fósforo na composição química de Gelidium crinale (Turner) Lamouroux (Gelidiaceae, Rhodophyta). Biotemas, v. 18 , v. 1, p. $7-26,2005$.

POLZIN, J. P.; RORRER, L. G. Halogenated monoterpene production by microplantlets of the marine red alga Ochtodes secundiramea within an airlift photobioreactor under nutrient medium perfusion. Biotechnology and Bioengineering, v. 82, n. 4, p. 415-427, 2003.

REIS, R. P. et al. Efeito de fatores bióticos no crescimento de Hypnea musciformis (RHODOPHYTA - GIGARTINALES). Acta Botanica Brasilica, v. 17, n. 2, p. 279-286, 2003.

RORRER, G.; CHENEY, D. Bioprocess engineering of cell and tissue cultures for marine seaweeds. Aquaculture Engineering, v. 32, n. 1, p. 11-41, 2004.
SERRANO, L. A. L; CATTANEO, L. F. O cultivo do mamoeiro no Brasil. Revista Brasileira de Fruticultura, v. 32, n. 3 p. 657-959, 2010.

TALARICO, L.; MARAZANA, G. Light and adaptive responses in red macroalgae: an overview. Journal of Photochemistry and Photobiology, v. 56, n. 1, p. 1-11, 2000.

VORAGEN, A. G. J. Technological aspects of functional food-related carbohydrates. Trends in Food Science \& Technology, v. 09, n. 8/9, p. 328-335, 1998.

YOKOYA, N. S.; YONESHIGUE-VALENTIN, Y. Micropropagation as a tool for sustainable utilization and conservation of populations of Rhodophyta. Revista Brasileira de Farmacognosia, v. 21, n. 2, p. 334-339, 2011.

YOKOYA, N. S. et al. Growth responses and photosynthetic characteristics of wild and phycoerythrin-deficient strains of Hypnea musciformis (Rhodophyta). Journal Applied Phycology, v. 19, n. 3, p. 197-205, 2007. 